Article

\title{
Innovative Techniques for Landscape Recovery after Clay Mining under Mediterranean Conditions
}

\author{
Diana Turrión ${ }^{1,+}$, Luna Morcillo ${ }^{1,+}$ D, José Antonio Alloza ${ }^{1}$ and Alberto Vilagrosa ${ }^{1,2, *(D)}$ \\ 1 Mediterranean Center for Environmental Studies (CEAM Foundation), Joint Research Unit University \\ of Alicante-CEAM, University of Alicante, 03690 Alicante, Spain; diana.turrion@ua.es (D.T.); \\ luna_morcillo@hotmail.com (L.M.); jantonio@ceam.es (J.A.A.) \\ 2 Department of Ecology, University of Alicante, 03690 Alicante, Spain \\ * Correspondence: a.vilagrosa@ua.es \\ + Both authors contributed equally to this study.
}

check for updates

Citation: Turrión, D.; Morcillo, L.; Alloza, J.A.; Vilagrosa, A. Innovative Techniques for Landscape Recovery after Clay Mining under Mediterranean Conditions. Sustainability 2021, 13, 3439. https://doi.org/10.3390/su13063439

Academic Editor: Jon Burley

Received: 29 January 2021

Accepted: 17 March 2021

Published: 19 March 2021

Publisher's Note: MDPI stays neutral with regard to jurisdictional claims in published maps and institutional affiliations.

Copyright: (c) 2021 by the authors. Licensee MDPI, Basel, Switzerland. This article is an open access article distributed under the terms and conditions of the Creative Commons Attribution (CC BY) license (https:// creativecommons.org/licenses/by/ $4.0 /)$.

\begin{abstract}
Open-pit mining results in profound modifications at different environmental scales that may persist for very long time periods, or even indefinitely. Considerable research efforts in mine reclamation strategies have been made, although reclamation failures are still common. In dry climates, such as in the Mediterranean Basin, successful actions may depend on features related to proper species selection and restoration techniques, which may substantially contribute to provide substrate stability and facilitate the regeneration of the main ecological processes. In this context, we developed the TECMINE case-study aimed to evaluate the feasibility and suitability of innovative restoration practices applied to clay-mine reclamation under Mediterranean conditions. The restoration strategy was designed at the landscape level with two main approaches: the recovery of natural geomorphology shapes and ecological restoration, including vegetation recovery and soil quality, based on proper reference ecosystems. After the geomorphological land remodeling, a combination of several innovative restoration techniques was implemented to reclaim plant communities and ecosystem functioning. These techniques involved: (i) accurate species selection according to microhabitat characteristics; (ii) high-quality plant production; (iii) surface remodeling to improve substrate stabilization; and (iv) implementing rainfall collection to enhance resources availability, soil fertility improvement and the amelioration of abiotic conditions for seedlings. Finally, we developed a monitoring program to assess the success of the implemented restoration techniques over time. The application of these innovative techniques has reported interesting results and represents a step forward in the improvement of mine restoration under Mediterranean climate.
\end{abstract}

Keywords: quarry reclamation; ecological restoration; Geofluv ${ }^{\mathrm{TM}}$, Mediterranean vegetation; ecosystem functioning; stress-tolerant species; TECMINE Project

\section{Introduction}

1.1. Open-Pit Mining Landscape's Impacts and Traditional Reclamation Approaches in Limiting Environments

Industrial-scale mineral extraction entails one of the most dramatic and durable landscape transformations [1]. The direct impacts of open-pit mining methods are usually complete topsoil removal and altered geomorphological landscapes, which often leave hostile environments to be recolonized by vegetation or animals, and directly affect biodiversity and carbon sequestration $[2,3]$.

Similarly, the disposal of non-profitable material extraction on the surface leaves long-lasting evidence for environmental transformations from mining. These modifications to surface and subsurface environments may persist for very long time periods, or even indefinitely, when mining activity ends.

In recent decades, increasing interest has been shown in not only restoring or mitigating mine impacts given the influence of growing environmental concern, but in also 
adopting more sustainable mining practices $[4,5]$. At the same time, many government regulations and laws have begun to develop mine closure guidelines [6,7].

Technical mine reclamation strategies (i.e., the combined process by which adverse environmental effects of surface mining are minimized and mined landscapes are returned to a beneficial end use) have been the focus of substantial research efforts and frequent expert meetings [8-10] among others. However, reclamation failures are common, frequently related to faults in reclamation execution, inadequate species selection, poor seedling quality, unsuitable restoration techniques, changes in legislation, post-mining land uses, and the impact of local disturbances not considered in reclamation management [11-13].

In reclaimed areas under dry climates, as in the Mediterranean Basin, successful actions may specifically depend on features related to water shortage and soil erosion that determine vegetation dynamics [14-16], which is considered a key factor that contributes to provide substrate stability and to facilitate the regeneration of fundamental ecological processes $[17,18]$. The increasingly extensive drought periods and the torrential patterns of rainfall events that occur in these ecosystems will, therefore, determine vegetation performance and erosion processes. Overland flow can be a triggering force in these cases as it redistributes soil particles (erosion and sedimentation) and water (runoff and soil moisture) on the slope scale $[19,20]$, whose negative impacts may vary according to vegetation cover and plant spatial patterns [21]. As part of conventional reclaiming actions, such as the construction of artificial slopes, the incipient development of soil devoid of vegetation and structure favors overland flow run-off and limits rainfall infiltration [22,23]. In some cases, extra overland flows run into reclaimed slopes from the top, which can promote soil erosion and directly affect plant dynamics and reclaiming success [24].

In mine reclamation terms, it is important to distinguish between practices for recovering vegetation and slope stabilization, and practices for restoring ecosystem functioning on different scales. Traditionally, efforts have been made in the first group by testing which species are feasible by considering critical conditions (i.e., lack of soil, scarce precipitation, high runoff, etc.), which may provide more functions besides soil stabilization and plant cover. For instance, in most Mediterranean reclamation projects, fast-growing herbaceous species have been predominantly preferred over shrubs in order to quickly cover soil and reduce the erosion risk. However, these actions have involved sacrificing colonization by other native species due to fierce competition for certain resources like water and soil [25]. Another usual practice in Mediterranean mining restoration is to supply high irrigation rates after planting to ensure plant survival [13]. Nevertheless, irrigation implies infrastructures, as well as high maintenance costs and water use, at sites where it is scarce, and the short duration of the effect may not compensate such investment [26]. Predominantly in berms and platforms designs, plantation has been usually restricted to a limited variety of tree and shrub species with high tolerance to critical conditions (i.e., species like Aleppo pine, Rosemary or Thyme). Once again, the lack of suitable soil and water availability limit the potential of mine sites to enhance biodiversity and other ecosystems services, as several reports warn $[27,28]$.

\subsection{An Ecological Restoration Approach for Mining Reclamation: Objectives and Guidelines}

According to the Society for Ecological Restoration, ecological restoration is the process of assisting the recovery of an ecosystem that has been degraded, damaged or destroyed [29]. The ecological restoration of degraded lands that involves introducing or naturally colonizing native species should implement field techniques to maximize water availability and nutrients to ensure seedling establishment, survival and growth [30]. In mitigation terms, restoration contributes to increase both capacity carbon fixation and carbon stock by introducing seedlings and providing suitable conditions for the natural colonization of native species [31]. Especially in mining reclamation where disturbance on pre-existing soil and vegetation is often extreme, reclamation is an implemented measure to compensate $\mathrm{CO} 2$ emissions from industrial activities [32]. 
Therefore, the main objectives of the ecological restoration of vegetation applied to mining reclamation should be: (i) slope stabilization by minimizing runoff and degradation processes in incipient substrates; (ii) increasing the water-holding capacity of soil and soil fertility; (iii) enhancing the establishment and growth of new introduced seedlings; (iv) ameliorating conditions for germination and the establishment of new native colonizing species to accelerate ecological succession processes.

Following the most innovative guidelines in ecological restoration [33,34], we suggest drawing up a list of consecutive steps to achieve the pursued objectives:

1. Analyzing the demand for natural capital and ecosystem services.

2. Identifying appropriate native reference ecosystems to optimize the potential for local species and communities to recover through well-targeted restoration actions, and to continue to reassemble and evolve in the face of change.

3. Address within-site heterogeneity by identifying landscape functional units and designing specific actions for each unit.

4. Introducing vegetation according to heterogeneity and natural spatial patterns.

5. Choose a large set of species to match the potential diversity of habitats, ecological conditions and management objectives. According to the potential vegetation in the area, introducing trees and shrubs with high potential cover and good capacity to develop a dense canopy and to accumulate litter, and for fast recovery from disturbances to confer the whole ecosystem good resilience.

6. Foster spontaneous plant growth by applying organic amendments.

7. Improve plantation success by using recent research results and applying innovative techniques to specifically reduce abiotic stress (hole plantation, water harvesting treatments, tree-shelters, mulch, organic amendments). Regarding climate adaptation, when designing species selection and site preparation techniques, current and future climate conditions that increase the ecosystem's resistance to new changes must be considered. The main objective of all these techniques is to support plant establishment during early post-planting stages.

8. Prevent damage due to overland flow by creating soil-retaining vegetation barriers.

9. Set up an effective monitoring system that allows the status and trends of selected indicators to be measured and helps to identify the necessary corrective actions and modifications.

\subsection{Limiting Factors to Reclaim Open-Pit Clay Mines in the Mediterranean}

For any mine exploitation type, several limitations come into play that may condition the success of ecological restoration under Mediterranean conditions [35]. On the local scale, substrate instability deriving from the erosive effect of runoff will condition abrupt shifts in vegetation dynamics [36]. Hydrological modifications imply alterations to water availability for plants [37]. Nutrient loss occurs through runoff, erosion, leaching and plant cover removal [38], and directly impacts soil fertility [39]. All these limitations specifically affect restoration actions applied to open-pit clay mines. Disposal on the surface of non-profitable clay material devoid of other textures and soil structure creates an impermeable layer that makes water percolation to deeper layers difficult and promotes overland flow [40]. These factors alter the slope relief, which determines substrate stability and the amount of infiltrated water due to efficient runoff water evacuation [41], which condition edaphic humidity distribution. It is a well-known fact that soil's capacity to hold water largely depends on soil texture. Although clay can hold the most water of all soil textures, very fine micropores retain water so tightly that plants find it very difficult to extract all of it. Therefore, most plants are unable to extract water beyond the wilting point (i.e., where water is held microscopically with too much energy for a plant to extract), as determined by fine textures [42]. This limitation directly affects the establishment of plant communities in both the initial restoration phase of and its evolution toward more complex ecosystems. 


\section{The Case Study: The TECMINE Project from the Ecological Restoration Approach}

The TECMINE Project was implemented at the Fortuna mine located in Ademuz (Valencia Province, Spain) $\left(40^{\circ} 06^{\prime} 50.38^{\prime \prime}\right.$ N, $\left.1^{\circ} 09^{\prime} 32.21^{\prime \prime} \mathrm{W}\right)$ (Figure 1). The area surrounding the mine shows two differentiated domains as part of the Mediterranean climate: subhumid located over 1100 masl and dry-subhumid around 950 masl reflecting a gradient under climate conditions. The mean annual temperatures range from 9.5 to $15.1^{\circ} \mathrm{C}$, and the mean annual precipitation values are between 443 and $627 \mathrm{~mm}$. The prevailing lithology comes from the Cretaceous period, mostly from the Albian age (facies Utrillas and Weald). The most representative soil around the project area corresponds to Regosols eutrics. According to the bioclimatic classification, the vegetation in the area corresponds to: (i) the Supramediterranean (above 1000 masl), dominated by Juniperus thurifera and Quercus rotundifolia, and hemicryptophytic pastures where Juniperus sabina is present; (ii) the Mesomediterranean (900-1500 masl), dominated by a community with Quercus coccifera, Ulex parviflorus and Cistus albidus species that alternate with agricultural fields and reforestations areas with pines.

The geological profile in the TECMINE Project was specifically characterized by the intercalation of successive layers of Kaolinite-feldspathic white sand separated by red clay levels. The thickness of this profile exceeded $100 \mathrm{~m}$, and contained seven available sand layers whose thicknesses ranged from 4 to $15 \mathrm{~m}$. Over these layers of industrial interest lay several well-organized strata ranging from calcarenitic sandstone to calcareous lithology. To fill the mining hole after exploitation in TECMINE, several clay and sand layers were placed by following the design of land shapes that derived from the Geofluv ${ }^{\mathrm{TM}}$ method using the Natural Regrade software [43,44].

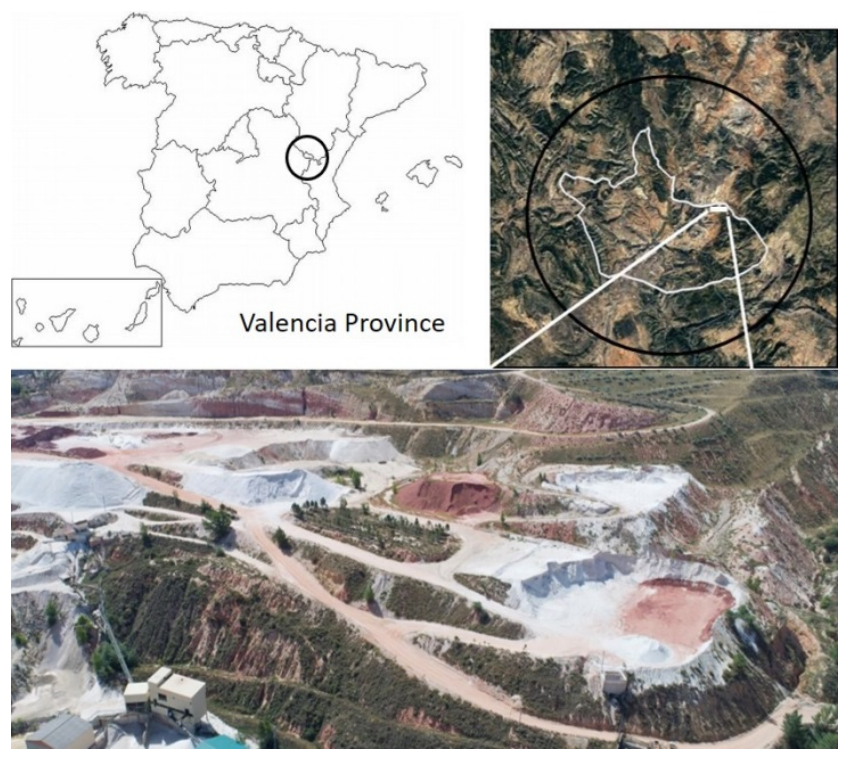

Figure 1. Location map of the Fortuna open-pit clay mine in Valencia Province, Spain.

We used the following approach to carry out the ecological restoration of the area:

\subsection{Identifying Landscape Functional units According to the Different Physiographic Conditions}

We identified three main areas according to the landscape characteristics and restoration objectives: (1) platform mine area; (2) talus-berm area on very steep surfaces; (3) permanent pond area (Figure 2). The platform mine area was the most extensive restoring area (ca. $5 \mathrm{ha}$ ) with a main central drainage channel. After applying the Geofluv ${ }^{\mathrm{TM}}$ method, the restoring area resulted in smoothed land-shapes, mainly dominated by slopes lower than $15 \%$, a smaller proportion of the surface with slopes between $15 \%$ and $30 \%$, and some localized areas with slopes exceeding 30\% (Figure 3; Step 1). 


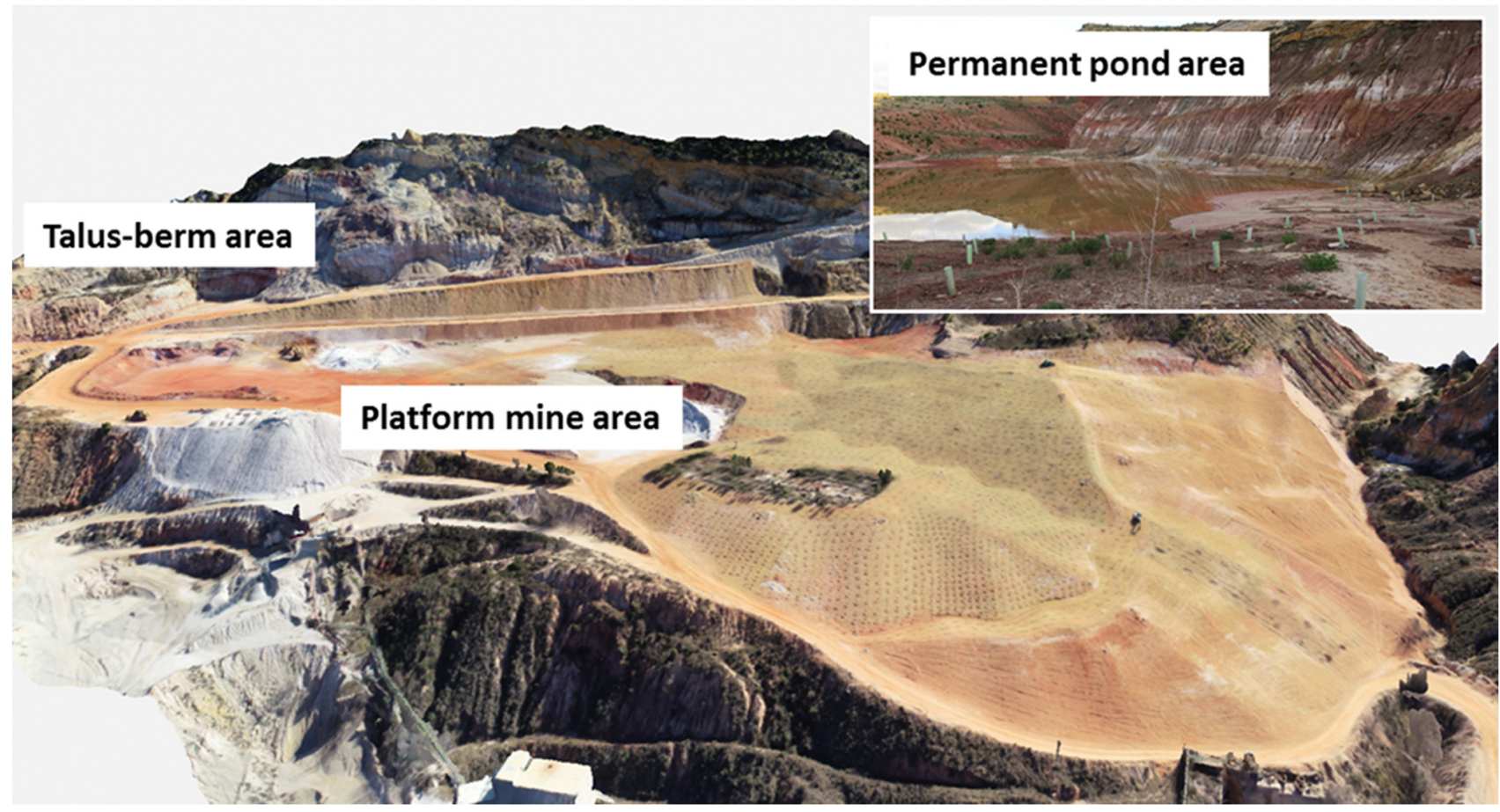

Figure 2. General view of the main three areas to be restored (i.e., platform mine area, talus-berm area, permanent pond area), obtained after geomorphological modeling. The Geofluv ${ }^{\mathrm{TM}}$ method was performed in the platform mine area, the talus-berm technique was applied due to the presence of steep slopes in the area, and no modeling was carried out in the pond area.

1)

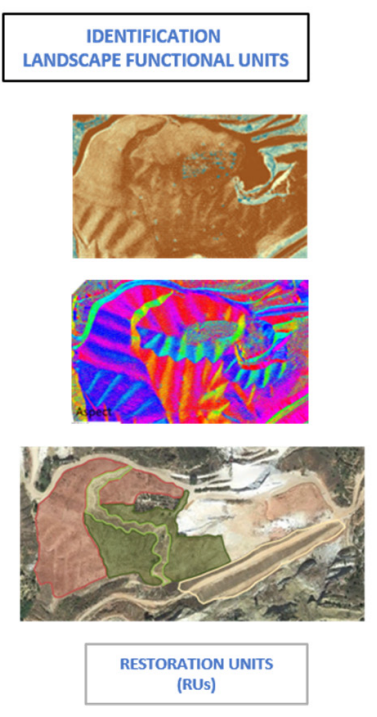

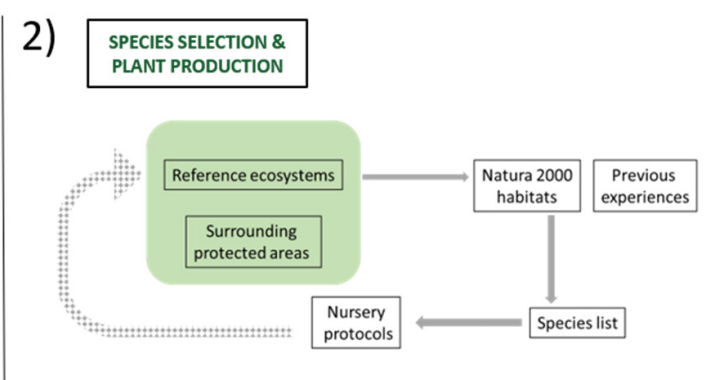

3) SUbstrate SURface StabiLIZATION

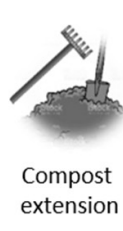

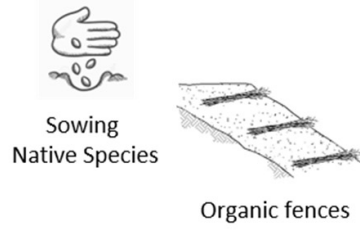

\section{4) REFORESTATION TECHNIQUES}
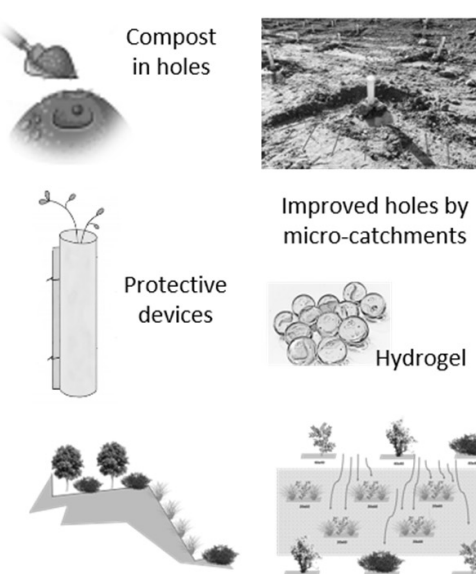

Improved holes by micro-catchments
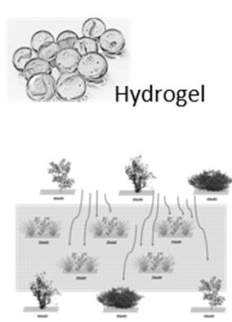

Specific solutions for talus-berm and permanent pond areas

Figure 3. Summary of the steps followed in the restoration strategy. We first identified the main areas to restore and delimited the restoration units (1); second, we established the guidelines for species selection, plant production and nursery culture (2); third, we determined suitable techniques to stabilize the substrate surface (3); finally, we implemented specific field restoration techniques in each restoration area depending on their main characteristics and species selection (4).

According to these characteristics, three restoration units (RUs) were identified in the platform mine area: RU1, the steepest area with slopes ranging from $15 \%$ to $30 \%$ whose aspect went from northwest to north; RU2, the flattest area with slopes ranging from $0 \%$ to $15 \%$, dominated by north-facing slopes; RU3, mainly in the bottom part, which constituted the drainage channel. The constituted talus-berm area (RU4), which covered 
approximately 0.1 ha and was located on very steep adjacent surfaces next to the platform mine area (Figure 4; left). In this unit, geomorphological remodeling consisted of systems with flat "berm" areas and steep slopes above 30\%. Finally, the permanent pond area (RU5), covering ca. 0.4 ha, resulted in a seminatural wetland area (Figure 4; right) to which no geomorphological restoration was applied.
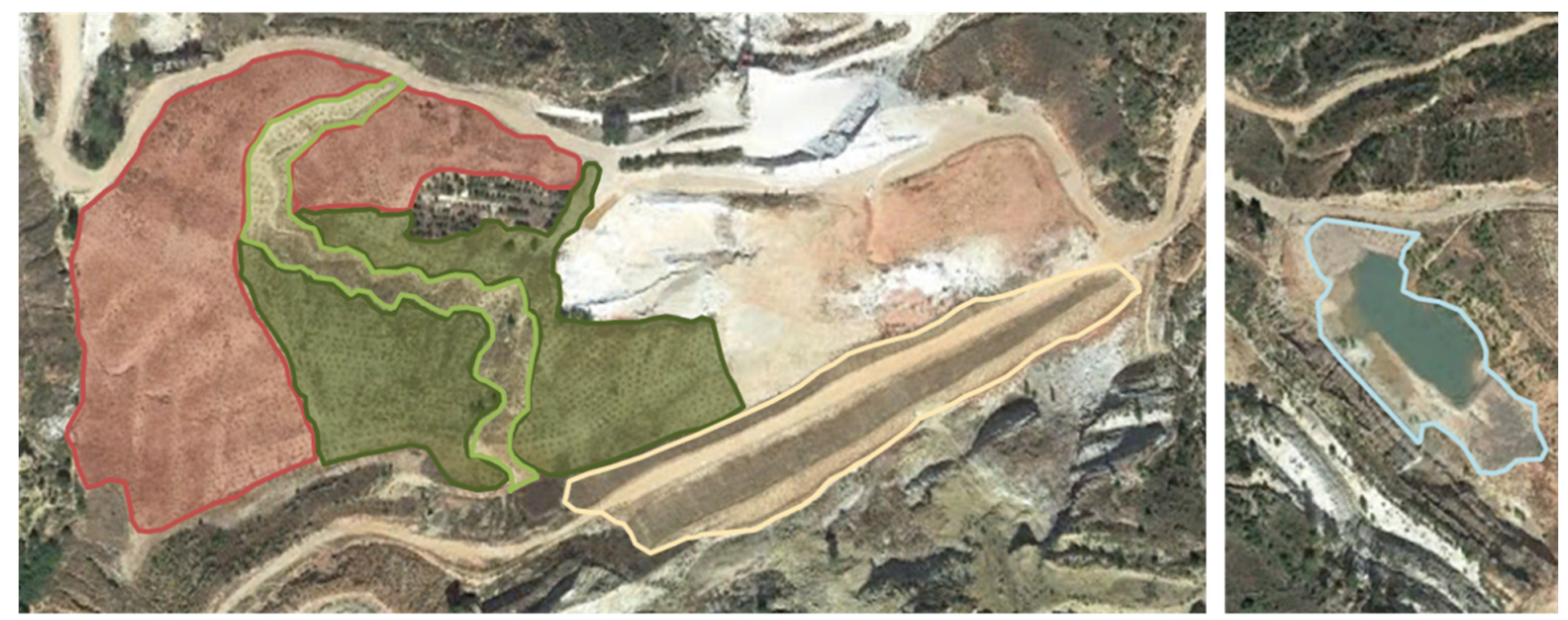

\section{Restoration units}
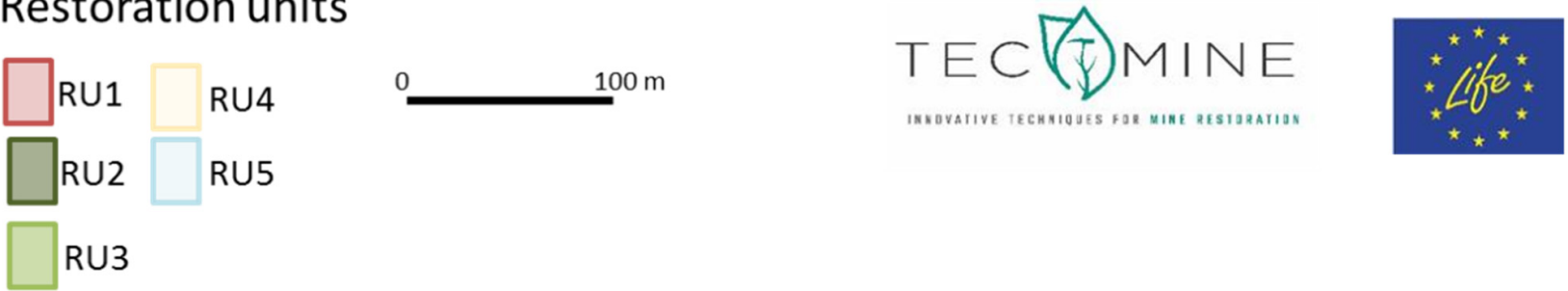

Figure 4. Aerial images showing the restored areas and the distribution of restoration units (RUs). Different colored polygons were assigned for each RU. Thus, RU1 is shown in red; RU2 in dark green; RU3 in light green; RU4 in yellow (left); and RU5 in blue (right).

\subsection{Species Selection and Plant Production}

Species selection and its composition were based on: (1) the heterogeneity and spatial patterns present in the reference ecosystems; (2) previous reforestation experiences under Mediterranean conditions; (3) the species present in surrounding protected areas, such as The Puebla de San Miguel Natural Park with a long list of well conserved ecosystems for supplying seeds for nursery cultivation purposes; (4) the list of Natura 2000 habitat types in this area after the Interpretation Manual of European Union Habitats-EUR28. Moreover, species selection had to meet the following requirements: (i) evergreen trees and shrubs with high potential ground cover; (ii) good capacity to develop a dense canopy and to accumulate litter; (iii) fast recovery capacity after disturbances to confer the whole ecosystem resilience.

During the TECMINE Project, we selected a large set of species choices to match the potential diversity of habitats, ecological conditions and management objectives. For this purpose, we set out to restore eight different habitat types by reintroducing 31 species (Table S1). Prior to reforestation procedures and techniques, we followed specific plant production and nursery culture guidelines. We first collected the seeds from local populations. We then started plant production and pre-treatments to break the dormancy of some species, such as Juniperus sp. Once germinated, we carried out the nursery culture during one vegetative period (i.e., 1 year) for most species, and two vegetative periods for slow-growing species. Seedlings grew on standard growing substrate, a mixture of peat and coconut fibers, in $300 \mathrm{~cm}^{3}$ forest trays $(18 \mathrm{~cm}$ deep). The herbaceous species for 
the permanent pond were cultivated in $500 \mathrm{~cm}^{3}$ forest trays. Seedlings were moderately irrigated. At the end of the nursery period, they were drought-preconditioned to improve the responses to water stress in the field after planting. Seedling acclimation to freezing temperatures was achieved by moving them to the nursery closest to the TECMINE area in the last month of culture period.

\subsection{Substrate Stabilization Techniques}

After mining activities, the substrate surface where restoration was implemented offered poor stability and could be affected by erosive processes that would compromise its permanence. Actions aimed to reduce soil surface exposure to erosive agents, such as raindrops sealing soil surface or runoff processes, were required. Thus, increasing soil roughness by soil amendments, such as the seeding of herbaceous species or installing organic fences by breaking surface water flows, can help to stabilize the soil surface and allow vegetation establishment and development. In TECMINE, the following techniques were applied for this purpose (Figure 3; Step 3):

The application of organic amendments on the soil surface: fertility has been identified as a main limiting factor for mining restoration due to the lack of storage of a topsoil layer with a sufficient nutrient content to sustain plant growth. Organic amendments or refuses (i.e., biosolids) may compensate these physico-chemical drawbacks by improving vegetation development $[45,46]$ and stimulating microbial activity $[47,48]$. However, this effect was not permanent and could disappear after a few years [26]. In TECMINE, composted sewage sludge mixed with pruning refuse $(10 \%)$ was spread in the substrate surface at a rate of 20 tons / ha (Table 1).

Sowing native herbaceous species: introducing herbaceous species is one of the most useful techniques for conferring soil protection [49]. This treatment promotes quick plant cover that increases surface roughness and results in improved soil physical properties, such as infiltration, water retention capacity or structural stability to prevent the loss of resources against runoff. It also creates microsites to establish native colonizing vegetation. We sowed a seed blend consisting of 50\% Dactylis glomerata and 50\% Lotus corniculatus throughout the restoration area. Doses and species mixture were in accordance with previous experiences [50-52].

Organic fences to promote slope roughness: there are several purposes for arranging banded forest refuses as kindling wood or chopped forestry refuses along slopes to: (i) attenuate runoff and erosion processes; (ii) create micro-environments like fertility islands; (iii) promote refuges for small fauna. This treatment consists of strips arranged in parallel to contour lines along slopes. Spatial distribution followed an interspersed design to promote water flow disruption and to favor its role as traps for sediments, seeds, etc. This treatment was implemented in RU1 (Figure S1), where long steep slopes are present. Organic fences were 3-5 $\mathrm{m}$ long, $50 \mathrm{~cm}$ wide and $20 \mathrm{~cm}$ thick.

Organic mesh to control erosion runoff: this widespread technique offers the possibility of protecting unstable steep slopes and restoring vegetation. We installed rolls of organic mesh composed of natural fibers on the steep slopes in the talus-berm area (RU4) by fixing them to the ground surface. At the same time, we also sowed herbaceous species to allow substrate surface stabilization, while vegetation grew along these surfaces.

\subsection{Reforestation Strategy and Techniques}

Different techniques were implemented according to the specific characteristics in each unit (Figure 3; Step 4) as follows:

(a) Platform mine area: combined techniques were applied as a result of its extension and its contrasted physiographic characteristics.

Standard holes improved by microcatchments: an adequate planting hole size is a determinant to favor root expansion during the first periods after planting, specifically during ecological restoration under Mediterranean climate conditions. The main microcatchment technique goals are to capture runoff water (runoff harvesting) and promote 
infiltration to seedlings' root zones. Microcatchments consisted of two small channels (1-1.5 m long) on both sides of the planting hole that conduct runoff to seedlings (Figure S2). Microcatchments were constructed over smoothed slope areas, such as RU2 and RU3, and were not set on steep slopes due to possible uncontrolled runoff by water accumulation in upper locations, i.e., RU 1 (Table 1).

Fertilization with composted organic waste: planting holes may benefit from the application of biosolids that act as a slow-release fertilizer. Biosolids also promote microbial activity and increase water-holding capacity. These amendments have been frequently used as supplementary treatments to accelerate the recovery of mining areas [53-55]. During our project, the composted sewage sludge was poured into each planting hole before seedling plantation and was well mixed with the substrate until complete substrate homogenization. According to previous experiments [56], the applied dose was $2 \mathrm{~kg}$ of compost per hole $(0.4 \times 0.4 \times 0.4 \mathrm{~m})$ (Table 1$)$.

Treeshelters and protective mesh: these protective devices keep plants from hard abiotic and biotic conditions that can be harmful for inserted seedlings, such as high temperature and radiation during summer periods or herbivory. Most tested species have exhibited a positive response to treeshelters, including some grown in degraded soils under Mediterranean conditions $[13,57,58]$. The commonest treeshelters consist of plastic tubes (60 $\mathrm{cm}$ long, about $15 \mathrm{~cm}$ in diameter) provided by holes to ensure air circulation. This type of treeshelters was installed on the tree and shrub species in RU1, RU2 and RU3 (Table 1). Protective mesh was also installed over dwarf shrubs species in RU1 to protect seedlings against herbivory, which was the case of Brachypodium sp., Lavandula latifolia, Rosmarinus officinalis and Psoralea bituminosa.

Hydrogels: these compounds are artificial hydro-absorbent polymers designed to increase the water-holding capacity of soil and substrates. Enhancing water availability can be relevant in early post-planting stages as it provides seedlings with an extra water supply during initial root development [59]. However, it is important to consider soil properties before its use because one of the main constraints of hydrogels is that waterholding capacity may be limited by competition if clay contents in soil are high. During the TECMINE Project, hydrogels were applied after the soil textures analysis at a rate of $5 \mathrm{~g}$ dry weight/hole at the base of the planting holes in RU1, which was dominated by high fine and coarse sand contents (Table 1).

(b) Talus-Berm area:

Geomorphological restoration may be constrained in some areas with very steep slopes. One possible solution is to create areas known as talus-berm systems, characterized by flat areas alternating with areas of slopes exceeding $30 \%$. In the steep talus, the main technique was to assemble organic mesh and sow herbaceous species. Then, we dug small furrows (ca. $1 \mathrm{~m}$ long $\times 0.2 \mathrm{~m}$ wide) to establish three standard seedlings (Figure 3; Step 4). For each furrow, we planted three individuals of two species: two Brachypodium retusum and one Dorycnium pentaphyllum (Table S1). This selection falls in line with the species' morpho-functional characteristics, of quick radical and aerial growth, which favors the retention of water and sediments, and minimizes degradation processes. Furrows were interspaced and distributed to favor the distribution of infiltration and runoff through vegetation. We recommend planting shrub and tree species in berm and plain areas because they receive a large amount of resources during the rainy season, which allows these species to survive and develop. 
Table 1. Restoration units and the main characteristics and treatments applied to each unit.

\begin{tabular}{|c|c|c|c|c|c|}
\hline Restoration Units & Slope Treatments & Doses & Reforestation Treatments & Doses/Qty/Number & Natura 2000 Habitats \\
\hline \multicolumn{6}{|l|}{ Platform mine area } \\
\hline $\begin{array}{c}\text { RU1 } \\
\text { Drier (sun-exposed), steep } \\
\text { slopes }(>30 \%)\end{array}$ & $\begin{array}{l}\text {-Seeding } \\
\text {-Organic } \\
\text { fences }\end{array}$ & $\begin{array}{c}100-150 \mathrm{~kg} / \mathrm{ha} \\
1.5 \mathrm{Tn} / \mathrm{ha}\end{array}$ & $\begin{array}{l}\text { Standard holes }(40 \times 40 \times 40)\left({ }^{*} 1\right) \\
\text {-Mesh/Tree shelter } \\
\text {-Compost } \\
\text {-Hydrogels }\end{array}$ & $\begin{array}{c}1000 \text { holes } / \mathrm{ha} \\
\text { Depending on } \\
\text { the species } \\
2 \mathrm{~kg} / \text { hole }(125 \mathrm{Tn} / \mathrm{ha}) \\
5 \mathrm{~g} / \text { hole }\end{array}$ & * $6220,9340,5210$ \\
\hline $\begin{array}{c}\text { RU2 } \\
\text { Dry-mild areas, moderate slopes } \\
(15 \%-30 \%)\end{array}$ & $\begin{array}{l}\text {-Compost } \\
\text {-Seeding }\end{array}$ & $\begin{array}{c}20 \mathrm{Tn} / \mathrm{ha} \\
100-150 \mathrm{~kg} / \mathrm{ha}\end{array}$ & $\begin{array}{l}\text {-Standard holes }\left({ }^{*} 1\right)(40 \times 40 \times 40) \text { plus } \\
\text { microcatchments } \\
\text {-Tree shelter } \\
\text {-Compost }\end{array}$ & $\begin{array}{c}600 \text { holes } / \text { ha } \\
600 \text { units } / \text { ha } \\
2 \mathrm{~kg} / \text { hole }(125 \mathrm{Tn} / \mathrm{ha})\end{array}$ & $9340,5210, * 9560$ \\
\hline $\begin{array}{l}\text { RU3 } \\
\text { Wetter areas, bottom and valley } \\
\text { areas, flow accumulations, flat } \\
\text { areas, slopes }<15 \%\end{array}$ & -Seeding & $100-150 \mathrm{~kg} / \mathrm{ha}$ & $\begin{array}{l}\text {-Standard holes }\left({ }^{*} 1\right)(40 \times 40 \times 40) \text { plus } \\
\text { microcatchments } \\
\text {-Tree shelter } \\
\text {-Compost }\end{array}$ & $\begin{array}{c}600 \text { holes } / \text { ha } \\
600 \text { units } / \text { ha } \\
2 \mathrm{~kg} / \text { hole }(125 \mathrm{Tn} / \mathrm{ha})\end{array}$ & $5210, * 9530,9240$ \\
\hline \multicolumn{6}{|l|}{ Talus-Berm area } \\
\hline $\begin{array}{l}\text { RU4 } \\
\text { Adjacent flat "berm" areas with } \\
\text { uniform steep slopes "talus" }\end{array}$ & $\begin{array}{l}\text {-Seeding } \\
\text {-Organic mesh }\end{array}$ & $100-150 \mathrm{~kg} / \mathrm{ha}$ & $\begin{array}{l}\text {-Small furrows }(60 \times 20 \times 20) \\
\text {-Compost }\end{array}$ & $\begin{array}{c}1000 \text { holes } / \mathrm{ha} \\
2 \mathrm{~kg} / \text { hole (125 Tn/ha) }\end{array}$ & $* 6220,9340$ \\
\hline \multicolumn{6}{|l|}{ Permanent pond area } \\
\hline $\begin{array}{c}\text { RU5 } \\
\text { Seminatural wetland }\end{array}$ & -None & & $\begin{array}{l}\text {-Small holes }(20 \times 20 \times 20) \\
\text {-Standard holes }(40 \times 40 \times 40) \\
\text {-Tree shelter }\left({ }^{*}\right)\end{array}$ & $\begin{array}{l}1200 \text { holes /ha } \\
600 \text { holes/ha } \\
600 \text { units/ha }\end{array}$ & $\begin{array}{c}6420,92 \mathrm{~A} 0 \\
5210, * 9530,9240\end{array}$ \\
\hline
\end{tabular}

$\left.{ }^{*}\right)$ Habitat listed as priority habitats; $\left({ }^{*} 1\right)$ all holes include stone protection around the seedling; $\left({ }^{*} 2\right)$ applicable only to tree species. 


\section{(c) Permanent pond area:}

This area is characterized by a seminatural pond where water availability is not limited. The restoration strategy involved arranging standard plantations in bands surrounding the pond. Species selection depended on the distance to water and flooding oscillation. Consequently, for permanently flooded areas, we used wetland grasslands like Juncus sp., Scirpus holoschoenus, Phragmites sp. or Typha sp. in small plantation holes (ca. $0.2 \times 0.2 \times 0.2 \mathrm{~m}$ ). In a second line outside the temporally flooded area, we planted riparian forest tree galleries, such as Populus sp. or Tamarix sp., among other species (Table S1). Finally, the areas farthest away from water were planted with a combination of selected Mediterranean species as in RU3. No composted sewage sludge was applied to prevent the water eutrophication deleterious effect.

\subsection{Monitoring Program}

Setting up a monitoring program is essential for evaluating the success of restoration actions $[60,61]$. Monitoring allows to: (i) evaluate the effectiveness of implemented techniques; (ii) in terms of an adaptive management approach, detect critical stages which may compromise a lack of success in the restoration, and establish corrective measures if required; (iii) by means of indicators, objectively assess whether ecosystem services return to the restored area.

By considering the main ecosystem services during monitoring assessments, such as biodiversity, the hydrological cycle, desertification or carbon sequestration may be useful for quantifying the degree of success. To establish a baseline to which to compare, the same indicators must be measured in both well-preserved reference ecosystems and the restoring area.

During the TECMINE Project, the monitoring program pursued several purposes. In order to assess the success of the implemented species and reforestation techniques, we periodically evaluated the plant survival and growth (i.e., height and basal diameter) of the introduced plants. According to abundance, the suitable representation of the introduced species was randomly selected and labeled for monitoring purposes for the next few years. These indicators allow the detection of possible shortcomings or limitations, such as poor seedling shock quality [62,63], exposure to harsh environmental conditions [64] or predation [65]. Analyzing soil water availability for the first years after planting may prevent seedling mortality or physiological damage (i.e., xylem cavitation or photochemical damages) due to out-of-season drought or long summer periods. In fact, the continuous soil water content measures registered during TECMINE warned us about very low water content values because of a dry period occurring immediately after planting, which implied the need for a punctual irrigation treatment in the first spring.

In relation to soil stabilization, plant cover dynamics are a proper indicator of effective cover in soil protection terms against erosive processes [66]. During TECMINE, seasonal inventories are programmed to acquire information about the presence, cover, growth and phenological status of both introduced and colonizer species, which have been tested as good indicators to establish the effect of sowing and plant native colonization [67]. Average height and species dominance allow plant community performance to be determined in the restored area. With all the measured variables, it is possible to obtain proxy indicators of plant biodiversity, such as specific richness, biodiversity indices or relative species abundance. The use of drones provided by visible and red and NDVI sensors, and later image analyses, were also included in the TECMINE monitoring program to identify changes in plant cover according to different abiotic conditions (soils, treatments, slope aspects) on a large scale, and to make comparisons to similar adjacent areas with native vegetation.

The ultimate purpose of mine restoration projects is to recover ecosystem functioning and vegetation dynamics. With this scope, during the TECMINE Project we planned to analyze plant biomass evolution, soil fertility, $\mathrm{C}$ sequestration and other parameters related to the hydrological cycle. These parameters are related to primary production, climate regulation, carbon storage and water provision [68]. To estimate the C fixation capacity of 
both soil and plants after restoration, we stablished soil analytical assessments over time, as well as above- and below-ground biomass determinations, in the main representative species. In order to establish water dynamics on the plant community scale, which provided information about the use of water from rainfall in the restored area, we planned to apply computer hydrological models, such as the HYDROBAL model [69], at the end of the project. This model estimates the main hydrological parameters (i.e., evapotranspiration, infiltration, soil water reserve, deep percolation, etc.) according to the vegetation structure, soil characteristics, soil water dynamics and climate conditions in the area.

\section{Results Analysis and Lessons Learned}

(1) Starting from a good base: after land remodeling, procuring suitable substrate is a crucial step to achieve successful ecological restoration [70]. If a topsoil stockpile is not stored for its later redistribution, then preparing a well-balanced mixture of the nonprofitable materials available at the mine will confer proper texture, porosity and stoniness to enhance water-holding capacity, soil protection and plant root development. Sandy loam and sandy clay loam textures in mine soils are generally considered favorable for tree growth [71]. During TECMINE, a layer of colluvium from surface edaphic layers was spread over a large area of the restored surface. This layer guaranteed a balanced proportion of sand, silt and clay compared to the clay and sand layers that result from exploitation refuse (Table 2). In addition, the colluvium placed over the restored area substantially increased stoniness, which can contribute to prevent soil compaction problems [72]. In specific areas where the colluvium layer was not thick enough, and when combined with slopes above $30 \%$, erosive processes took place with the consequent appearance of rills and gullies (Figure S3), which highlights the importance of substrate properties.

Table 2. Substrate texture (sand, silt and clay contents) and the stoniness of the three main materials found in the mine. The sandy and clay substrate corresponded to exploitation refuses.

\begin{tabular}{cccccc}
\hline & $\begin{array}{c}\text { Sand } \\
(\mathbf{\%})\end{array}$ & $\begin{array}{c}\text { Silt } \\
\mathbf{( \% )}\end{array}$ & $\begin{array}{c}\text { Clay } \\
\mathbf{( \% )}\end{array}$ & $\begin{array}{c}\text { Stoniness } \\
\mathbf{( \% )}\end{array}$ & $\begin{array}{c}\text { Texture } \\
\text { Classification }\end{array}$ \\
\hline Colluvium & 43 & 35 & 22 & 53 & Loam \\
Sandy substrate & 84 & 12 & 7 & 12 & Sandy \\
Clay substrate & 6 & 62 & 32 & 65 & Silty-clay \\
\hline
\end{tabular}

(2) Soil nutrient availability requirements: organic amendments, if conveniently applied to sterile substrates, have positive effects on soil fertility and vegetation development. The soil analysis performed after applying compost during TECMINE showed a significant increase in all the nutritional parameters (Table 3). Addition of compost in planting holes also gave positive responses for the introduced seedlings in all the restoration units. Survival rate values ranged from $70 \%$ to $90 \%$ (Figure 5) at 20 months after planting. Growth rates (Figure 6) resulted in RGR values above 1, which means a 3-fold increase in size in relation to the planting date. The initial size of some species like Psoralea bituminosa, Rhamnus alaternus, Rhamnus lycioides, Colutea arborescens and Pistacia terebinthus increased even more than 7-fold. According to the literature, this positive response to nutrient addition is especially expected during seedling establishment in optimal conditions, when plants are in an exponential growth phase that results in increased production and improved plant performance $[73,74]$. In TECMINE, these positive effects of organic amendments on vegetation may be compromised if some aspects like dose, quality and application type are not conveniently considered [46,52]. 
Table 3. Soil analytical parameter values before and after soil surface compost application.

\begin{tabular}{ccc}
\hline & Before Compost Application & After Compost Application \\
\hline OM $(\%)$ & 0.47 & 6.99 \\
N $(\%)$ & 0.04 & 0.31 \\
SOC $(\%)$ & 0.27 & 4.06 \\
C $/ \mathrm{N}$ & 5.88 & 12.77 \\
\hline
\end{tabular}

Legend: organic matter $(\mathrm{OM})$; total nitrogen $(\mathrm{N})$; soil organic carbon $(\mathrm{SOC})$; carbon-nitrogen $(\mathrm{C} / \mathrm{N})$ ratio.

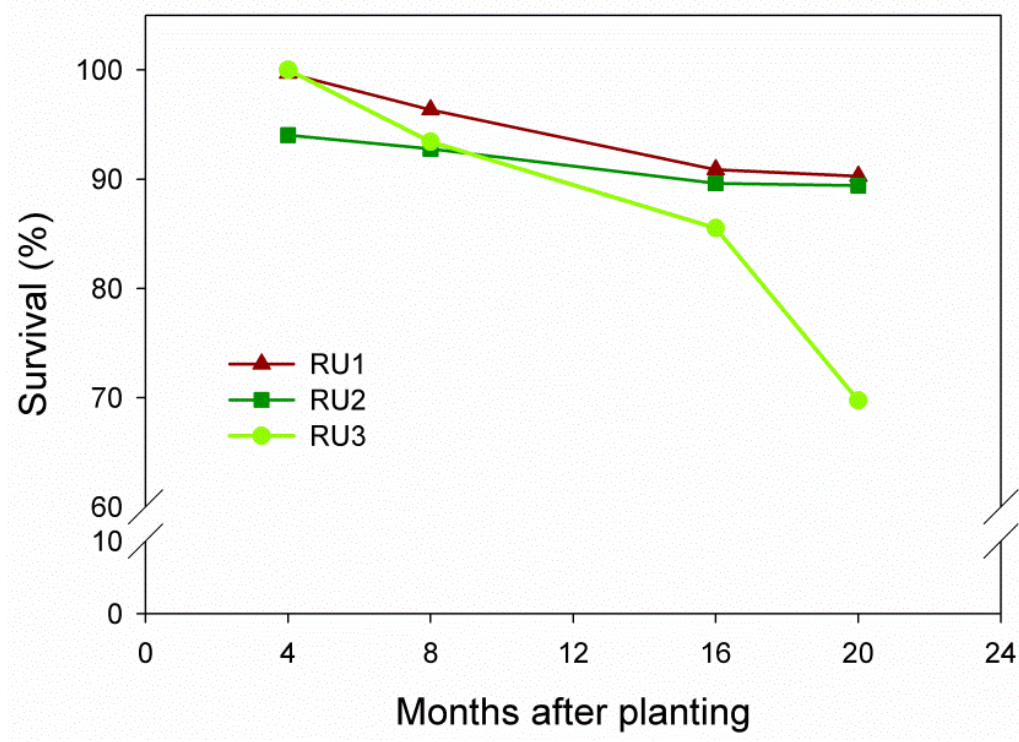

Figure 5. Species survival dynamics (\%) 20 months after planting for each restoration unit. Red line with triangles represents RU1, the dark green line with squares represents RU2 and light green line with circles represents RU3. Dates go from 19 March to 20 November.

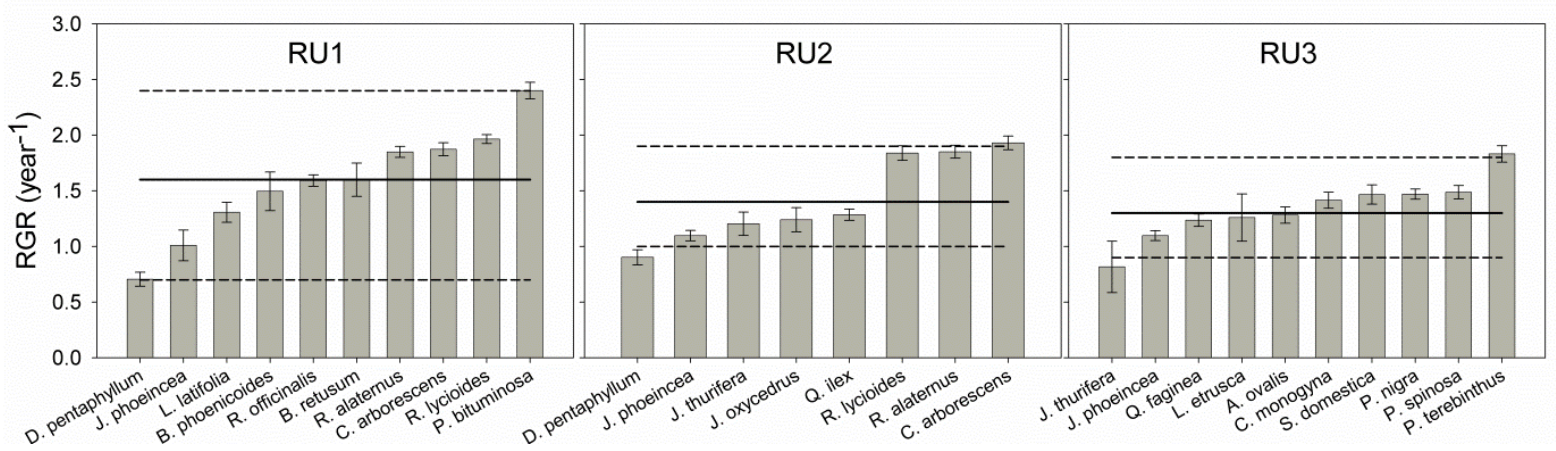

Figure 6. Relative growth rates (RGR) in plant height for each species (mean $\pm \mathrm{SE}$ ). Values are represented by gray vertical bars and organized by restoration units: RU1 (left plot), RU2 (middle plot), RU3 (right plot). The mean values of each RU are represented by solid lines, and the maximum and minimum values by dotted lines. RGR was calculated as the difference between the ln-transformed values of the total plant height for the study period (from July 2019 to September 2020) and the difference of time is expressed in years (year-1).

(3) Promoting effective soil cover: herbaceous species play a key role in soil stabilization in early stages after land remodeling [75]. Sowing native species in proper doses is crucial in preventing a very fierce competitive effect with both introduced seedlings and colonizing vegetation [52]. After one year of restoration during TECMINE, most of the initial bare soil was covered by herbaceous species (Figure S4). The herbaceous cover exceeded $40 \%$ throughout RU (Figure 7), which may suffice to effectively control erosive processes [76]. 


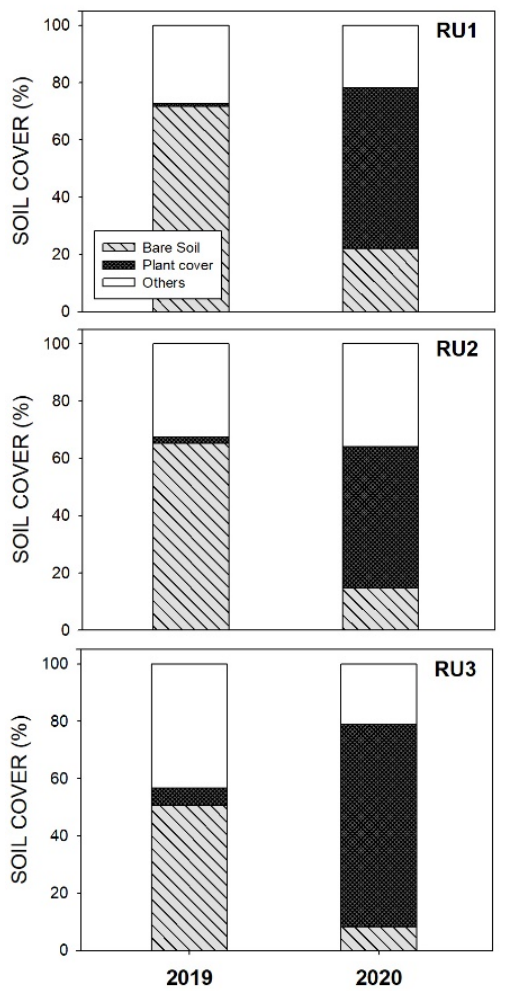

Figure 7. Soil cover (\%) in the different restoration units (RU1, RU2, RU3) for Spring 2019 and Spring 2020. Different colors and textures were assigned to the various cover categories. Bare soil is shown in grey with lines, Plant cover in dark gray and, Others in white. Others refers to different categories such as stones, blocks, compost and litter.

(4) Accurate species selection, seed provenance and suitable plant nursery techniques: determining proper ecosystem references allows detailed species selection to be carried that suits the specific physiographic characteristics of the restoring area. Moreover, if this selection is conducted on a microhabitat scale, it will entail high plant diversity levels that guarantee the good adaptation of the plants introduced into the new restored environment and in turn, local seed provenance ensures good adaptation to local conditions. We also recommend carrying out the nursery period in an infrastructure near the restoration area to guarantee good seedling acclimatization to the abiotic conditions of the area where they are introduced. This statement in our project certainly involved successful survival and growth rates to date, independently of each restoration unit characteristics and limitations (Figures 5 and 6).

(5) Low-cost actions with many associated benefits: it has been widely reported that resources management may improve ecosystem functioning and the provision of services, while minimizing costs $[30,77]$. The use of innovative low-cost techniques appears to be a good option to optimize resource availability rather than other more expensive options like irrigation systems [78]. Microcatchments have been previously tested with positive results in improving in surface water use efficiency by incrementing water soil storage in planting holes [79]. Our preliminary results in soil moisture dynamics on the planting hole scale showed that microcatchments had a positive effect with increased soil moisture around $7 \%$ in RU2 and RU3 in relation to the standard holes of RU1 where no microcatchments were constructed (Figure 8). 


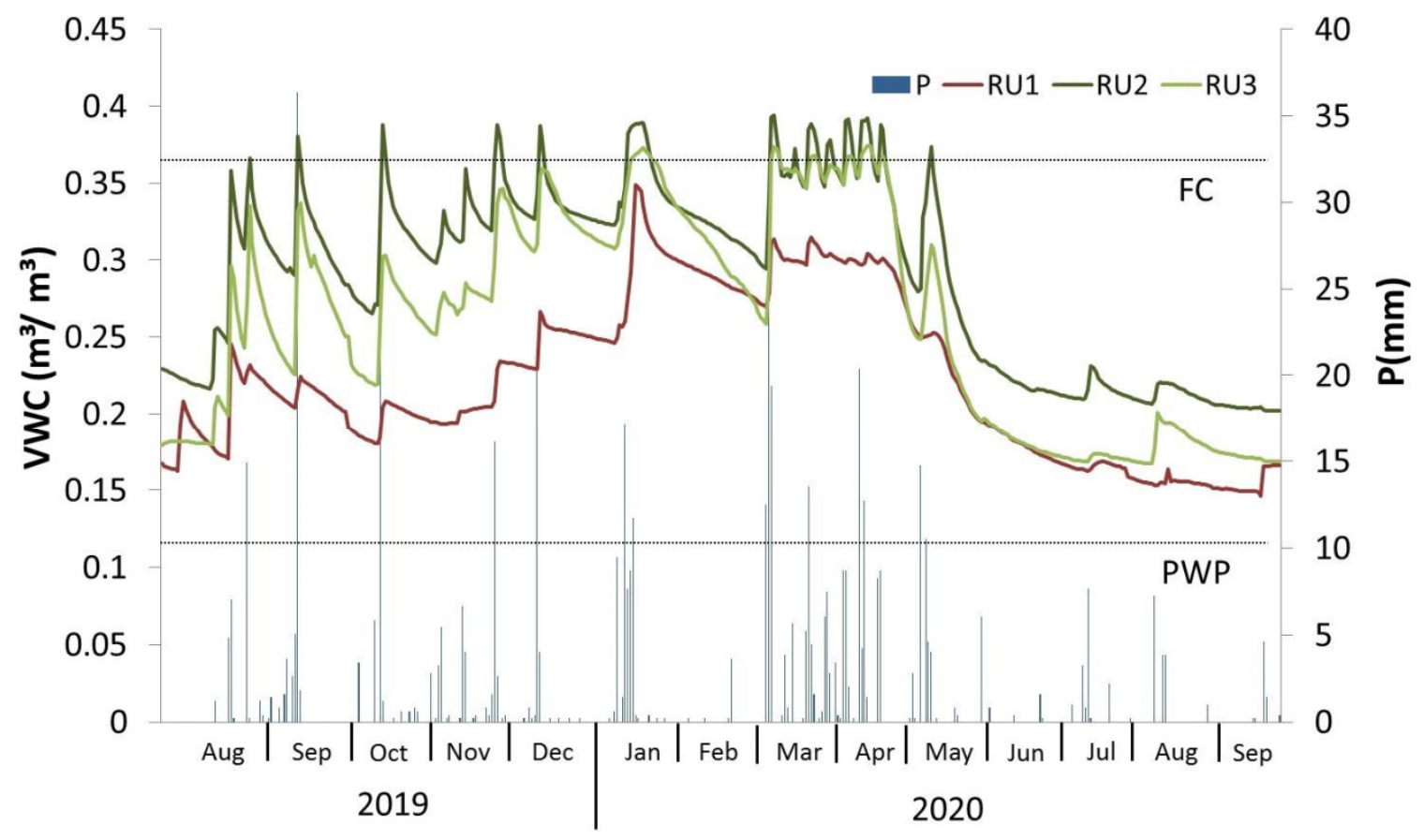

Figure 8. Volumetric water content (VWC) of soils on a daily basis for the different restoration units (RU, RU2, RU3) (left axis). The vertical blue bars represent the precipitation values recorded by the meteorological station installed in the TECMINE area (right axes). Field capacity (FC) and permanent wilting point (PWP) values (dotted lines). Data are shown from 19 August to 20 September.

(6) Sustainability and circular economy claims: TECMINE aims to contribute to sustainability from the integration of society, the environment and local economy. It is necessary to look for more sustainable production systems to reduce employed resources and waste. During the TECMINE Project, we applied these statements by promoting local employment and taking waste materials from close areas, such as chopped wood from silvicultural pruning in close forests or organic composted amendments from a close sewage sludge plant. The new restored space can contribute to the area's socio-economic development by welcoming new uses, such as ecotourism or recreational activities, which have an impact on the local population's income.

\section{Conclusions and Recommendations}

The quality of the topsoil selected for reclaiming the area is essential. A proper texture together with a well-balanced stoniness proportion will enable a good development of the vegetation, avoiding negative effects such as surface crusting, high runoff, and soil losses during rainfalls. The fertilization of this topsoil with low-cost composted refuses such as sewage sludge will provide an adequate nutrient content for the vegetation development. Moreover, these recycling residues practices promote sustainability and a circular economy.

Regarding vegetation establishment, it is important to promote the rapid colonization by sowing herbaceous species that cover and efficiently protect the soil. Additionally, the plantation of native trees and shrub species will accelerate the recovery of the natural vegetation in the restored area. A careful species selection will facilitate high survival and growth rates independently of the biotic conditions, even in the most unfavorable sites. The introduction of non-native species should be avoided due to the risk of introducing invasive species.

The application of low-cost restoration field techniques such as micro-catchments instead of more expensive irrigation systems will produce a positive effect on seedling establishment and growth, reducing the costs and the waste of water in climates with important water limitations as occurs in drylands. 
Supplementary Materials: The following are available online at https: / www.mdpi.com/2071-1 050/13/6/3439/s1, Table S1: Habitat and species selection according to Natura 2000. Figure S1: General view of the organic fences distribution; Figure S2: Microcatchment technique; Figure S3: Comparison between substrates; Figure S4: Plant cover dynamics.

Author Contributions: Conceptualization, D.T., L.M., J.A.A. and A.V.; methodology, D.T., L.M., J.A.A. and A.V.; investigation, D.T., L.M. and A.V.; data curation, D.T.; writing-original draft preparation, D.T. and L.M.; writing-review and editing, D.T., L.M., J.A.A. and A.V. All authors have read and agreed to the published version of the manuscript.

Funding: The study was funded by the LIFE TECMINE Project (LIFE16 ENV/ES/000159) from the European Programme for the Environment and Climate Action (2014-2020)*. L.M. was supported by the Spanish MICINN (PTA2019-018094). The CEAM foundation is funded by the Generalitat Valenciana. ${ }^{*}$ NB: This publication reflects solely the opinions of the authors, and the TECMINE Commission is not responsible for any use that may be made of the information herein contained.

Institutional Review Board Statement: Not applicable.

Informed Consent Statement: Not applicable.

Data Availability Statement: Not applicable.

Acknowledgments: We thank the LIFE EU program which is an important funding instrument for the environment and climate action (ec.europa.eu/easme/en/life (accessed on 1 March 2021)). We thank the TECMINE partnership consortium: GVA and Vaersa (coordination and management tasks), CIEF (plant production), UCM and UNIZAR (geomorphological design and soil-water dynamics monitoring) and SIBELCO (mining company, remodeling and field works). We also thank D. Fuentes from Ecodrone Works for the image analysis support.

Conflicts of Interest: The authors declare no conflict of interest.

\section{References}

1. Beckett, C.; Keeling, A. Rethinking remediation: Mine reclamation, environmental justice, and relations of care. Local Environ. 2019, 24, 216-230. [CrossRef]

2. Cooke, J.A.; Johnson, M.S. Ecological restoration of land with particular reference to the mining of metals and industrial minerals: A review of theory and practice. Environ. Rev. 2002, 10, 41-71. [CrossRef]

3. Moreno-Mateos, D.; Barbier, E.B.; Jones, P.C.; Jones, H.P.; Aronson, J.; López-López, J.A.; McCrackin, M.L.; Meli, P.; Montoya, D.; Rey Benayas, J.M.R. Anthropogenic ecosystem disturbance and the recovery debt. Nat. Commun. 2017, 8, 14163. [CrossRef]

4. Hilson, G.; Murck, B. Sustainable Development in the Mining Industry: Clarifying the Corporate Perspective. Resour. Policy 2000, 26, 227-238. [CrossRef]

5. Whitmore, A. The Emperor's New Clothes: Sustainable Mining? In Sustainable Mineral Operations in the Developing World; Marker, B.R., Petterson, M.G., McEvoy, F., Stephenson, M.H., Eds.; Geological Society Special Publications: London, UK, 2005 ; pp. $233-242$.

6. Worrall, R.; Neil, D.; Brereton, D.; Mulligan, D. Towards a Sustainability Criteria and Indicators Framework for Legacy Mine Land. J. Clean. Prod. 2009, 17, 1426-1443. [CrossRef]

7. Bainton, N.A.; Holcombe, S. The Social Aspects of Mine Closure: A Global Literature Review; Centre for Social Responsibility in Mining (CSRM), Sustainable Minerals Institute (SMI), The University of Queensland: Brisbane, Australia, 2018.

8. Hammack, R.W.; Edenborn, H.M.; Dvorak, D.H. Treatment of water from an open-pit copper mine using biogenic sulfide and limestone: A feasibility study. Water Res. 1994, 28, 2321-2329. [CrossRef]

9. Pepper, M.; Roche, C.P.; Mudd, G.M. Understanding Life of Mine Across Time and Space, Life of Mine Conference; Mining Legacies: Brisbane, Australia, 2014; pp. 449-465.

10. Wang, H.; Zhang, B.; Bai, X.; Shi, L. A novel environmental restoration method for an abandoned limestone quarry with a deep open pit and steep palisades: A case study. R. Soc. Open Sci. 2018, 5, 180365. [CrossRef]

11. Nicolau, J.M.; Moreno-de las Heras, M. Opencast mining reclamation. In Forest Restoration in Landscapes: Beyond Planting Trees; Mansourian, S., Vallauri, D., Dudley, N., Eds.; WWF/Springer: Berlin, Germany, 2005; pp. 370-376.

12. Bautista, S.; Aronson, J.; Vallejo, V.R. Land Restoration to Combat Desertification. Innovative Approaches, Quality Control and Project Evaluation; Fundación CEAM: Valencia, Spain, 2009.

13. Vallejo, V.R.; Smanis, A.; Chirino, E.; Fuentes, D.; Valdecantos, A.; Vilagrosa, A. Perspectives in dryland restoration: Approaches for climate change adaptation. New For. 2012, 43, 561-579. [CrossRef]

14. Whisenant, S.G. Manipulation of the physical environment. Terrestrial systems. In Handbook of Ecological Restoration. Principles of Restoration; Perrow, M.R., Davy, A.J., Eds.; Cambridge University Press: Cambridge, UK, 2002; Volume 1, pp. 83-105.

15. Martinez-Ruiz, C.; Fernandez-Santos, B.; Putwain, P.D.; Fernandez-Gomez, M.J. Natural and man-induced revegetation on mining wastes: Changes in the floristic composition during early succession. Ecol. Eng. 2007, 30, 286-294. [CrossRef] 
16. Josa, R.; Jorba, M.; Vallejo, R.V. Opencast mine restoration in a Mediterranean semi-arid environment: Failure of some common practices. Ecol. Eng. 2012, 42, 183-191. [CrossRef]

17. Sänger, H.; Jetschke, G. Are assembly rules apparent in the regeneration of a former uranium mining site? In Assembly Rules and Restoration Ecology: Bridging the Gap between Theory and Practice; Temperton, V.M., Hoobs, R.J., Nuttle, T., Halle, S., Eds.; Island Press: Washington, USA, 2004; pp. 305-324.

18. Moreno-de Las Heras, M.; Nicolau, J.M.; Espigares, T. Vegetation succession in reclaimed coal-mining slopes in a Mediterraneandry environment. Ecol. Eng. 2008, 34, 168-178. [CrossRef]

19. Lavee, H.; Imeson, A.C.; Sarah, P. The impact of climate change on geomorphology and desertification along a Mediterranean-arid transect. Land Degrad. Dev. 1998, 9, 407-422. [CrossRef]

20. Puigdefábregas, J.; Solé, A.; Gutiérrez, L.; Del Barrio, G.; Boer, M. Scales and processes of water and sediment redistribution in drylands: Results from the Rambla Honda field site in SE Spain. Earth Sci. Rev. 1999, 48, 39-70. [CrossRef]

21. Bautista, S.; Mayor, A.G.; Bourakhouadar, J.; Bellot, J. Plant spatial pattern predicts hillslope runoff and erosion in a semiarid Mediterranean landscape. Ecosystems 2007, 10, 987-998. [CrossRef]

22. Ward, A.D.; Wells, L.G.; Phillips, R.E. Infiltration through reconstructed surface mined spoils and soils Trans. ASAE 1983, 26, 821-832. [CrossRef]

23. Guebert, M.D.; Gardner, T.W. Macropore flow on a reclaimed surface mine: Infiltration and hillslope hydrology. Geomorphology 2001, 39, 151-169. [CrossRef]

24. Moreno-de las Heras, M.; Nicolau, J.M.; Espigares, M.T. Interacción entre la erosión en regueros, contenido de humedad edáfica y colonización vegetal en laderas restauradas de la minería a cielo abierto del carbón en ambiente mediterráneo-continental (Teruel). In Estudios de la Zona No Saturada del Suelo; Samper-Calvete, F.J., Paz-González, A., Eds.; Universidade da Coruña: La Coruña, Spain, 2005; Volume 7, pp. 345-350.

25. Jorba, M.; Ninot, J.M.; Vallejo, V.R. Las siembras en la revegetación de zonas afectadas por minería. Ingeopres Actual. Técnica Ing. Civ. Min. Geol. Medio Ambiente 2007, 166, 30-35.

26. Soliveres, S.; Gutiérrez-Acevedo, E.; Moghli, A.; Cortina, J. Effects of early irrigation and compost addition on soil and vegetation of a restored semiarid limestone quarry are undetectable after 13 years. J. Arid. Environ. 2021, 186, 104401. [CrossRef]

27. Starke, L. Good Practice Guidance for Mining and Biodiversity; International Council on Mining and Metals (ICMM): London, UK, 2006; p. 142.

28. Non-Energy Mineral Extraction and NATURA 2000 Guidance Document Publications Office of the European Union; European Commission: Luxembourg, 2011.

29. Gann, G.D.; McDonald, T.; Walder, B.; Aronson, J.; Nelson, C.R.; Jonson, J.; Hallett, J.G.; Eisenberg, C.; Guariguata, M.R.; Hua, F.; et al. International principles and standards for practice of ecological restoration. Restor. Ecol. 2019, 27, 1-46. [CrossRef]

30. Rey-Benayas, J.; Newton, A.C.; Diaz, A.; Bullock, J.M. Enhancement of biodiversity and ecosystem services by ecological restoration: A meta-analysis. Science 2009, 325, 1121-1124. [CrossRef] [PubMed]

31. Lu, F.; Hu, H.; Sun, W.; Zhu, J.; Liu, G.; Zhou, W.; Zhang, Q.; Shi, P.; Liu, X.; Wu, X.; et al. Effects of national ecological restoration projects on carbon sequestration in China from 2001 to 2010. Proc. Natl. Acad. Sci. USA 2018, 115, 4039-4044. [CrossRef]

32. Yang, B.; Bai, Z.K.; Cao, Y.G.; Xie, F.; Zhang, J.J.; Wang, Y.N. Dynamic Changes in Carbon Seques-tration from Opencast Mining Activities and Land Reclamation in China's Loess Plateau. Sustainability 2019, 11, 1473. [CrossRef]

33. Vallejo, V.R. Problems and perspectives of Dryland Restoration. In Land Restoration to Combat Desertification. Innovative Approaches, Quality Control and Project Evaluation; Bautista, S., Aronson, J., Vallejo, V.R., Eds.; Fundación de Estudios Ambientales del Mediterraneo CEAM: Valencia, Spain, 2009; pp. 13-22.

34. Aronson, J.; Goodwin, N.; Orlando, L.; Eisenberg, C.; Cross, A.T. A world of possibilities: Six restoration strategies to support the United Nation's Decade on Ecosystem Restoration. Restor. Ecol. 2020, 28, 730-736. [CrossRef]

35. Balaquer, L.; Nicolau, J.M.; García, A. Revegetación de espacios mineros desde la perspectiva de la restauración ecológica. In Restauración Ecológica en Minería. de la Teoría a la Práctica; García, A., Travieso, J.R., Eds.; Fundación Ciudad de la Energía, Ponferrada: León, Spain, 2012; pp. 87-108.

36. Mayor, A.G.; Bautista, S.; Rodriguez, F.; Kefi, S. Connectivity-Mediated Ecohydrological Feedbacks and Regime Shifts in Drylands. Ecosystems 2019, 22, 1497-1511. [CrossRef]

37. Miranda, J.D.D.; Armas, C.; Padilla, F.M.; Pugnaire, F.I. Climatic change and rainfall patterns: Effects on semi-arid plant communities of the Iberian Southeast. J. Arid Environ. 2011, 75, 1302-1309. [CrossRef]

38. Bertol, I.; Mello, E.L.; Guadagnin, J.C.; Zaparolli, A.L.V.; Carrafa, M.R. Nutrient losses by water erosion. Sci. Agric. 2003, 60, 581-586. [CrossRef]

39. Maiti, S.K. Biodiversity Erosion and Conservation in Ecorestored Site. In Ecorestoration of the Coalmine Degraded Lands; Springer: New Delhi, India, 2013; pp. 187-199.

40. Nicolau, J.M.; Moreno de las Heras, M.; Merino, L.; Espigares, T. Bases eco- hidrológicas para aplicar la restauración ecológica en minería. In Restauración Ecológica en Minería. De la Teoría a la Práctica; García, A., Travieso, J.R., Eds.; Fundación Ciudad de la Energía, Ponferrada: León, Spain, 2012; pp. 47-63.

41. Moreno de las Heras, M.; Nicolau, J.M.; Merino-Martín, L.; Wolcox, B.P. Plot scale effects on runoff and erosion along a slope degradation gradient. Water Resour. Res. 2010, 46, W04503. [CrossRef]

42. Kirkham, M.B. Principles of Soil and Plant Water Relations; Academic Press: San Diego, CA, USA, 2014. 
43. Zapico, I.; Duque, J.F.M.; Bugosh, N.; Laronne, J.B.; Ortega, A.; Molina, A.; Martín-Moreno, C.; Nicolau, J.M.; Castillo, L.S. Geomorphic reclamation for reestablishment of landform stability at a watershed scale in mined sites: The Alto Tajo Natural Park, Spain. Ecol. Eng. 2018, 111, 100-116. [CrossRef]

44. Hancock, G.R.; Duque, J.M.; Willgoose, G.R. Geomorphic design and modelling at catchment scale for best mine rehabilitationThe Drayton mine example (New South Wales, Australia). Environ. Model. Softw. 2019, 114, 140-151. [CrossRef]

45. Rotagno, C.M.; Sosebee, R.B. Surface application of biosolids in the Chihuahuan desert: Effects on soil physical properties. Arid. Land Res. Manag. 2001, 15, 233-244. [CrossRef]

46. Valdecantos, A.; Fuentes, D.; Cortina, J. Utilización de biosólidos para la restauración de ecosistemas mediterráneos. In Avances en el Estudio de la Gestión del Monte Mediterráneo; Vallejo, V.R., Alloza, J.A., Eds.; Fundación CEAM: Valencia, Spain, 2004; pp. 313-344.

47. Ros, M.; Hernández, M.T.; García, C. Soil microbial activity after restoration of a semiarid soil by organic amendments. Soil Biol. Biochem. 2003, 35, 463-469. [CrossRef]

48. Bastida, F.; Kandeler, E.; Moreno, J.L.; Ros, M.; García, C.; Hernández, T. Application of fresh and composted organic wastes modifies structure, size and activity of soil microbial community under semiarid climate. Appl. Soil Ecol. 2008, 40, 318-329. [CrossRef]

49. Andres, P.; Jorba, M. Mitigation strategies in some motorway embankments (Catalonia, Spain). Restor. Ecol. 2000, 8, 268-275. [CrossRef]

50. Bautista, S.; Abad, N.; Lloret, J.; Blade, C.; Ferran, A.J.; Ponce, M.; Alloza, J.A.; Bellot, J.; Vallejo, V.R. Siembra de herbáceas y aplicación de mulch para la conservación de suelos afectados por incendios forestales. In La Restauración de la Cubierta Vegetal de la Comunidad Valenciana; Vallejo, V.R., Ed.; Fundacion CEAM—Consellería de Agricultura y Medio Ambiente: Valencia, Spain, 1997; pp. 395-434.

51. Bautista, S.; Robichaud, P.R.; Bladé, C. Post-Fire Mulching. Fire Effects on Soils and Restoration Strategies; Science Publishers: Enfield, UK, 2009; pp. 353-372.

52. Jorba, M.; Ninot, J.M.; Vallejo, R.V. Respuesta de las intervenciones de restauración a medio plazo: Resultados del proyecto EcoQuarry en Cataluña. Cem. Hormigón 2011, 947, 48-58.

53. Moreno-Peñaranda, R. Plant species diversity as indicator of restoration quality: The case of soils amended with sewage sludge in abandoned quarries. In Desertification in Europe: Mitigation Strategies, Land Use Planning; Enne, G., Zanolla, C., Peter, D., Eds.; European Communities: Brussels, Belgium, 2000; pp. 382-392.

54. Jorba, M.; Vallejo, R.; Josa, R.; Alcañiz, J.M.; Sole, A. Evaluación de experiencias piloto de restauración ecológica después de una década. Ingeopres 2001, 44-50.

55. Alcañiz, J.M.; Ortiz, O.; Carabassa, V. Utilización de Lodos de Depuradora en Restauración, Manual de Aplicaciones; Agencia catalana del agua, Generalitat de Cataluña: Barselona, Spain, 2009; p. 114.

56. Fuentes, D.; Valdecantos, A.; Llovet, J.; Cortina, J.; Vallejo, V.R. Fine-tuning of sewage sludge application to promote the establishment of Pinus halepensis seedling. Ecol. Eng. 2010, 36, 1213-1221. [CrossRef]

57. Bellot, J.; De Urbina, J.O.; Bonet, A.; Sánchez, J.R. The effects of treeshelters on the growth of Quercus coccifera L. seedlings in a semiarid environment. Forestry 2002, 75, 89-106. [CrossRef]

58. Piñeiro, J.; Maestre, F.T.; Bartolomé, L.; Valdecantos, A. Ecotechnology as a tool for restoring degraded drylands: A meta-analysis of field experiments. Ecol. Eng. 2013, 61, 133-144. [CrossRef]

59. Chirino, E.; Vilagrosa, A.; Vallejo, V.R. Using hydrogel and clay to improve the water status of seedlings for dryland restoration. Plant Soil 2011, 344, 99-110. [CrossRef]

60. Vallauri, D.; Aronson, J.; Dudley, N.; Vallejo, V.R. Monitoring and evaluating forest restoration success. In Forest Restoration in Landscapes; Springer: New York, NY, USA, 2005; pp. 150-158.

61. Rodríguez-Uña, A.; Cruz-Alonso, V.; Rohrer, Z.; Martínez-Baroja, L. Fresh perspectives for classic forest restoration challenges. Restor. Ecol. 2020, 28, 12-15. [CrossRef]

62. Burdett, A.N. Physiological processes in plantation establishment and the development of specifications for forest planting stock. Can. J. For. Res. 1990, 20, 415-427. [CrossRef]

63. Kozlowski, T.T. Water supply and tree growth. I. Water deficits. For. Abstr. 1982, 43, 57-95.

64. Folk, R.S.; Grossnickle, S.C. Determining field performance potential with the use of limiting environmental conditions. New For. 1997, 13, 121-138. [CrossRef]

65. Moles, A.T.; Westoby, M. What do seedlings die from and what are the implications for evolution of seed size? Oikos 2004, 106, 193-199. [CrossRef]

66. Bradshaw, A.D.; Chadwick, M.J. The Restoration of Land; the Ecology and Reclamation of Derelict and Degraded Land; Blackwell Scientific Publications: Oxford, UK, 1980.

67. Carabassa, V.; Ortiz, O.; Alcañiz, J.M. Evaluación y Seguimiento de la Restauración de Zonas Afectadas por Minería; CREAF y Departamento de Territorio y Sostenibilidad, Generalitat de Catalunya: Barcelona, Spain, 2015.

68. The Millennium Ecosystem Assessment (MEA). Ecosystems and Human Well-Being; Biodiversity Synthesis World Resources Institute: Washington, DC, USA, 2005; p. 86.

69. Bellot, J.; Chirino, E. Hydrobal: An eco-hydrological modelling approach for assessing water balances in different vegetation types in semi-arid areas. Ecol. Modell. 2013, 266, 30-41. [CrossRef] 
70. Zipper, C.E.; Burger, J.A.; Barton, C.D.; Skousen, J.G. Rebuilding soils on mined land for native forests in Appalachia. Soil Sci. Soc. Am. J. 2013, 77, 337-349. [CrossRef]

71. Burger, J.A.; Graves, D.; Angel, P.; Davis, P.; Zipper, C.E. The Forestry Reclamation Approach; U.S. Office of Surface Mining Forest Reclamation Advisory 2: Pittsburgh, PA, USA, 2005.

72. Lipiec, J.; Hatano, R. Quantification of compaction effects on soil physical properties and crop growth. Geoderma 2003, 116, 107-136. [CrossRef]

73. Kozlowski, T.T.; Kramer, P.J.; Pallardy, S.G. The Physiological Ecology of Woody Plants; Academic Press, Inc.: San Diego, CA, USA, 1991.

74. Binkley, D. Nutrición Forestal. Prácticas de Manejo; Editorial Limusa, S.A. de C.V.: Mexico City, Mexico, 1993 ; p. 518.

75. Prach, K. Spontaneous succession in Central-European man-made habitats: What information can be used in restoration practice? Appl. Veg. Sci. 2003, 6, 125-129. [CrossRef]

76. Thornes, J.B. The interaction of erosional and vegetational dynamics in land degradation: Spatial outcomes. In Vegetation and Erosion; Thornes, J.B., Ed.; John Wiley and Sons Ltd.: Chichester, UK, 1990; pp. 41-53.

77. Cortina, J.; Maestre, F.T.; Vallejo, V.R.; Baeza, M.J.; Valdecantos, A.; Pérez-Devesa, M. Ecosystem structure, function, and restoration success: Are they related? J. Nat. Conserv. 2006, 14, 152-160. [CrossRef]

78. Smanis, A.; Fuentes, D.; Fuente, P.; Valdecantos, A. How far Surface water fluxes determine restoration success in Mediterranean degraded áreas? Implications for dryland precision restoration. J. Arid Environ. 2021, 187, 104445. [CrossRef]

79. Fuentes, D.; Smanis, A.; Valdecantos, A. Recreating sink areas on semiarid degraded slopes by restoration. Land Degrad. Dev. 2017, 28, 1005-1015. [CrossRef] 